\title{
ANALISIS POTENSI LAHAN PERTANIAN PADI SAWAH DI KABUPATEN NIAS UTARA MEMANFAATKAN SISTEM INFORMASI GEOGRAFIS
}

\author{
Selamat Gea, Muhammad Ridha Syafii Damanik \\ Universitas Negeri Medan \\ JI. Willem Iskandar Pasar V Medan Estate \\ Email: s22gea@gmail.com
}

\begin{abstract}
Abstrak
Penelitian ini bertujuan untuk mengetahui (1) Karakteristik fisik wilayah kabupaten Nias Utara berdasarkan parameter IPL, (2) Potensi lahan pertanian padi sawah di Kabupaten Nias Utara. (3) Kelas IPL penggunaan lahan pertanian padi sawah di Kabupaten Nias Utara. Metode yang digunakan adalah metode pengharkatan (skoring) dan tumpang susun (overlay) dengan menggunakan sistem informasi geografis (SIG). Pengharkatan dan overlay dilakukan terhadap parameter-parameter penyusun Indeks Potensi Lahan yang meliputi kelerengan, litologi, jenis tanah dan hidrologi sebagai faktor pendukung serta kerawanan bencana erosi sebagai faktor pembatas. Hasil penelitian menunjukkan bahwa: (1) Wilayah Kabupaten Nias Utara sebagian besar memiliki lereng berombakbergelombang, litologi sedimen klastik berbutir halus, tekstur tanah agak halus, potensi air tanah kurang berpotensi, kerawanan longsor berpotensi ringan; (2) Kabupaten Nias Utara memiliki potensi lahan pertanian padi sawah kelas sangat tinggi seluas $14.381,44$ Ha (11,56\%), kelas tinggi seluas 15.529,58 Ha (12,48\%), kelas sedang seluas 40.770,89 $\mathrm{Ha}(32,77 \%)$, kelas rendah seluas 46.554,24 Ha (37,42\%), kelas sangat rendah seluas 7.182, 08 Ha (5,77\%); (3) Kelas IPL penggunaan lahan pertanian padi sawah di Kabupaten Nias Utara terdiri dari kelas sangat tinggi seluas 376,42 Ha (9,37\%), kelas tinggi 466,92 $\mathrm{Ha}(11,63 \%)$, kelas sedang seluas $1.633,98 \mathrm{Ha}(40,69 \%)$, kelas rendah seluas $1.476,40 \mathrm{Ha}$ (36,77\%), kelas sangat rendah seluas 61,74 Ha (1,54\%).
\end{abstract}

Kata Kunci-Potensi Lahan, Padi Sawah, Sistem Informasi Geografis

\section{PENDAHULUAN}

Sektor pertanian merupakan sektor yang sangat penting peranannya dalam perekonomian nasional. "NAWACITA atau agenda prioritas Kabinet Kerja periode 2014-2019 mengarahkan pembangunan pertanian ke depan untuk mewujudkan kedaulatan pangan, agar Indonesia sebagai bangsa dapat mengatur dan memenuhi kebutuhan pangan rakyatnya secara berdaulat" (Kementerian Pertanian, 2015).

Dalam pengembangan usaha pertanian, lahan merupakan sumber daya alam yang sangat penting. "Lahan adalah lingkungan fisik yang terdiri atas iklim, relief, tanah, air, dan vegetasi serta benda yang ada di atasnya sepanjang berpengaruh terhadap potensi penggunaan lahan" (FAO, 1976 dalam Arsyad, 1989). Suatu wilayah yang satu dengan wilayah lainnya memiliki kondisi fisik lahan yang bervariasi. Kondisi fisik lahan sering dinyatakan dengan potensi lahan yang sangat menentukan dalam penggunaan lahan beserta pengelolaan yang tepat sehingga dapat dicapai produktivitas yang optimal (Toyibulah, 2012).

Upaya penilaian lahan sesuai potensi lahan disebut Indeks Potensi lahan (Suharsono 1995 dalam Halengkara 2007). Indeks potensi lahan (IPL) memiliki beberapa parameter yaitu: tanah, relief, litologi, air tanah, dan kerawanan bencana. Pada masing-masing parameter tersebut, perlu dilakukan penilaian untuk mengetahui indeks potensi lahan pada suatu wilayah, semakin tinggi nilai indeks potensi lahan, maka tingkat potensi lahan di wilayah tersebut juga tinggi (Hamranani, 2014).

Padi merupakan komoditas tanaman pangan yang penting di Indonesia. Sembilan puluh lima persen penduduk Indonesia menjadikan beras sebagai bahan makanan pokok (Swastika, dkk, 2007 dalam Norsalis, 2011). Padi dapat dibedakan menjadi padi sawah dan padi gogo. Padi sawah biasanya ditanam di daerah dataran rendah yang memerlukan penggenangan, sedangkan 
padi gogo ditanam di dataran tinggi pada lahan kering Prihatman (2008 dalam Norsalis, 2011). Padi yang ditanam pada lahan yang berpotensi tinggi dapat menghasilkan padi yang berkualitas, produktivitas tinggi serta memiliki nilai ekonomis yang tinggi (Yentri dan Taryono, 2016).

Kabupaten Nias Utara merupakan daerah yang memiliki sektor unggulan dibidang pertanian. Pada tahun 2015, penduduk kabupaten Nias Utara yang termasuk dalam angkatan kerja atau berumur 15 tahun ke atas mayoritas bekerja di bidang pertanian yaitu 55.693 jiwa dari total 61.297 jiwa angkatan kerja atau 90,85 $\%$ (BPS Kabupaten Nias Utara, 2017). Komoditas utama tanaman pangan di kabupaten Nias Utara yaitu padi sawah (BPS Kabupaten Nias Utara, 2017). Berdasarkan peta penggunaan lahan Kabupaten Nias Utara tahun 2015 terdapat luas penggunaan lahan sawah yaitu 40,15 $\mathrm{km}^{2}$ atau 4015,46 ha $(3,23 \%$ dari luas wilayah Kabupaten Nias Utara).

Berdasarkan data BPS, rata-rata produktivitas padi sawah di kabupaten Nias Utara selama 5 tahun terakhir (2012-2016) sebesar 3,19 ton/tahun. Menurut Ditjen Tanaman Pangan (2013 dalam Indah, Zakaria, dan Prasmatiwi, 2015), produktivitas potensi padi sawah adalah sebesar 6,49 ton/ha. Ini menunjukkan bahwa produktivitas padi sawah di Kabupaten Nias Utara masih di bawah produktivitas potensial sehingga belum efisien.

Kabupaten Nias Utara sebagai daerah otonomi baru akan terus mengalami perkembangan dan pembangunan diberbagai bidang. Dalam hal ini, tidak menutup kemungkinan kedepannya akan terjadinya konversi lahan pertanian ke lahan non pertanian. Konversi lahan pertanian merupakan ancaman yang serius bagi ketahanan pangan nasional, sebab konversi lahan tersebut sulit dihindari dan dampaknya terhadap masalah pangan bersifat permanen, kumulatif, dan progresif (Irawan, 2007 dalam Yentri dan Taryono, 2016).

Penentuan indeks potensi lahan ini tentu akan lebih efisien jika disajikan spasial/keruangan (spasial variability). Batasbatas untuk tiap potensi lahan dapat diketahui dengan pasti pola keruangannya dan yang paling penting adalah posisi absolutnya. Pemetaan Indeks Potensi Lahan jika dilakukan secara manual maka membutuhkan waktu, tenaga, dan biaya yang tidak sedikit. Oleh karena itu diperlukan suatu metode yang paling efisien untuk dapat mengolah dan menganalisis data spasial dan data atribut yang berisi informasi lainnya untuk pembuatan peta indeks potensi lahan.

Aplikasi Sistem Informasi Geografi dapat dimanfaatkan untuk analisis potensi lahan padi sawah terutama dalam pengharkatan (scoring) dan tumpang susun (overlay) data parameter-parameter indeks potensi lahan. Sistem informasi geografis (SIG) adalah suatu sistem informasi berbasiskan komputer untuk memasukkan, menyimpan, memeriksa, mengintegrasikan, memanipulasi, menganalisis, dan menampilkan data yang berhubungan degan permukaan bumi (Rice, 2000, dalam Suryantoro, 2013). Teknologi SIC merupakan basis data spasial yang konsisten serta mempunyai aksesibilitas yang baik. SIC dibutuhkan karena untuk data spasial penanganannya sangat sulit dan selalu berubah dari waktu ke waktu, terutama karena peta dan data statistik cepat sekali kadaluwarsa (Suryantoro, 2013). SIC bisa menjadi alat yang sangat penting pada pengambilan keputusan untuk pembangunan berkelanjutan, karena SIC memberikan informasi pada pengambil keputusan untuk analisis dan basis data keruangan (Suryantoro, 2013). Maka perlu diadakan penelitian tentang "Analisis Potensi Lahan Pertanian Padi Sawah di Kabupaten Nias Utara dengan Memanfaatkan Sistem Informasi Geografi”.

Tujuan yang akan dicapai dalam penelitian ini adalah:

1. Menganalisis karakteristik fisik wilayah kabupaten Nias Utara berdasarkan parameter IPL

2. Menganalisis potensi lahan pertanian padi sawah di Kabupaten Nias Utara

3. Menganalisis kelas IPL penggunaan lahan pertanian padi sawah di Kabupaten Nias Utara.

\section{METODE PENELITIAN}

Penelitian ini dilaksanakan di Kabupaten Nias Utara. Alasan peneliti memilih lokasi penelitian tersebut karena Kabupaten Nias Utara memiliki sektor unggulan di bidang pertanian padi sawah, produktivitas padi sawah di kabupaten Nias Utara masih dibawah produktivitas potensial sehingga belum efisien, Kabupaten Nias Utara sebagai 
daerah otonomi baru akan terus mengalami perkembangan dan pembangunan di berbagai bidang, maka tidak menutup kemungkinan terjadinya konversi pertanian ke lahan non pertanian.

Tahapan persiapan penelitian berupa studi pustaka dan pengumpulan data. Studi pustaka terhadap sumber referensi yang berkaitan dengan penelitian. Data yang diperlukan merupakan data sekunder berupa peta dan informasi lainnya. Data bersumber dari instansi terkait yaitu: peta administrasi, peta kemiringan lereng, peta kerawanan bencana longsor, dan peta penggunaan lahan sawah dari BAPPEDA Kabupaten Nias Utara, peta air tanah dari Departemen Energi Dan Sumber Daya Mineral, peta litologi dari Pusat Penelitian dan Pengembangan Geologi, dan peta tekstur tanah dari BPDAS Asahan Barumun (BPDAS Barumun, 2016).

Teknik analisis data yang digunakan dalam penelitian ini adalah analisis deskriptif kuantitatif, yakni dengan penentuan harkat (skoring). Penelitian ini juga menggunakan teknik tumpang susun (overlay) beberapa peta untuk menghasilkan informasi baru yang kemudian dianalisis. Tiap-tiap peta parameter yang terdiri dari peta kemiringan lereng, peta litologi, peta tekstur tanah, peta potensi air tanah, dan peta kerawanan bencana longsor dilakukan pengharkatan berdasarkan tabel acuan pengharkatan parameter indeks potensi lahan dan ditumpangsusunkan (overlay). Kemudian dilakukan perhitungan nilai IPL menggunakan rumus IPL dan diklasifikasikan sehingga menghasilkan peta Indeks Potensi Lahan Kabupaten Nias Utara. Peta Indeks Potensi Lahan yang telah dibuat ditumpangsusunkan dengan peta penggunaan lahan padi sawah Kabupaten Nias Utara sehingga menghasilkan peta IPL penggunaan lahan padi sawah Kabupaten Nias Utara.

Indeks potensi lahan ditentukan berdasarkan jumlah keseluruhan dari harkat di tiap peta parameter pendukung IPL, yang kemudian dikalikan dengan harkat parameter pembatas yaitu kerawanan bencana. Perhitungan nilai indeks potensi lahan tersebut menggunakan rumus sebagai berikut (Suharsono, 1995, dalam Hidayati dan Toyibullah, 2011):

$$
\mathrm{IPL}=(\mathrm{R}+\mathrm{L}+\mathrm{T}+\mathrm{H}) \times \mathrm{B}
$$

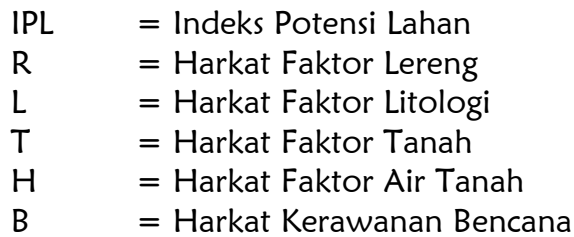

Kelas Indeks Potensi Lahan terbagi dalam 5 kelas yaitu: sangat rendah, rendah, sedang, tinggi, sangat tinggi. Kelas Indeks Potensi Lahan dapat diklasifikasikan setelah semua total harkat diketahui. Mengklasifikasi kelas IPL yaitu (Yentri dan Taryono, 2016):

$\mathrm{IPL}=\frac{\text { Nilai Tertinggi-Nilai Terendah }}{5}$

Faktor-faktor yang mempengaruhi indeks potensi lahan seperti ditunjukkan pada Tabel 1 sampai dengan Tabel 5 .

\begin{tabular}{|c|c|c|c|}
\hline \multirow[t]{2}{*}{ Kelas } & \multicolumn{2}{|c|}{ Kemiringan Lereng } & \multirow{2}{*}{$\begin{array}{l}\text { Har } \\
\text { kat }\end{array}$} \\
\hline & $\%$ & Relief & \\
\hline 1 & $0-5 \%$ & Datar Landai & 5 \\
\hline II & $5-15 \%$ & $\begin{array}{l}\text { Berombak- } \\
\text { Bergelombang }\end{array}$ & 4 \\
\hline III & $15-25 \%$ & Berbukit Rendah & 3 \\
\hline IV & $25-45 \%$ & Berbukit & 2 \\
\hline V & $>45 \%$ & Bergunung & 1 \\
\hline
\end{tabular}

Sumber: Suharsono, 1995, dalam Halengkara, 2007

TABEL 2. HARKAT FAKTOR TEKSTUR TANAH

\begin{tabular}{ccc}
\hline Kode & Kelas Tekstur & Harkat \\
\hline 1 & Kasar & 1 \\
2 & Agak Kasar & 4 \\
3 & Sedang & 5 \\
4 & Agak Halus & 3 \\
5 & Halus & 2 \\
\hline
\end{tabular}

Sumber: Suharsono, 1995, dalam Halengkara, 2007

TABEL 3. HARKAT FAKTORAIR TANAH

\begin{tabular}{ccc}
\hline Kode & Air Tanah & Harkat \\
\hline A1 & Sangat Berpotensi & 5 \\
A2 & Berpotensi & 4 \\
A3 & Potensi Sedang & 3 \\
A4 & Kurang Berpotensi & 2 \\
A5 & Langka air tanah & 0 \\
\hline
\end{tabular}

Sumber: Suharsono, 1995, dalam Halengkara, 2007

TABEL 4. HARKAT FAKTOR LITOLOGI

\begin{tabular}{ccc}
\hline Kode & Litologi & Harkat \\
\hline Lb & Batuan beku masif & 5 \\
\hline Lp & Batuan Piroklastik & 8 \\
\hline Lk & $\begin{array}{c}\text { Sedimen klastik } \\
\text { berbutir kasar }\end{array}$ & 5 \\
\hline Lh & $\begin{array}{c}\text { Sedimen klastik } \\
\text { berbutir halus }\end{array}$ & 2 \\
\hline
\end{tabular}

Keterangan : 


\begin{tabular}{ccc}
\hline $\mathrm{Lg}$ & $\begin{array}{c}\text { Sedimen } \\
\text { Gampingan dan } \\
\text { Metamorf }\end{array}$ & 3 \\
\hline $\mathrm{LI}$ & Batuan Camping & 5 \\
\hline $\mathrm{La}$ & $\begin{array}{c}\text { Aluvium / } \\
\text { Coluvium }\end{array}$ & 10 \\
\hline Sumber: Suharsono, 1995, dalam Halengkara, 2007
\end{tabular}

TABEL 5. HARKAT FAKTOR KERAWANAN BENCANA LONGSOR

\begin{tabular}{ccc}
\hline Kode & $\begin{array}{c}\text { Tingkat } \\
\text { Kerawanan } \\
\text { Tanah Longsor }\end{array}$ & Harkat \\
\hline E1 & Sangat Berat & 0,5 \\
E2 & Berat & 0,6 \\
E3 & Sedang & 0,7 \\
E4 & Ringan & 0,8 \\
E5 & Tanpa & 1,00 \\
\hline
\end{tabular}

Sumber: Suharsono, 1995, dalam Halengkara, 2007

\section{HASIL DAN PEMBAHASAN}

Karakteristik Fisik Wilayah Kabupaten Nias Utara Berdasarkan Parameter IPL

Wilayah Kabupaten Nias Utara sebagian besar memiliki lereng berombak bergelombang seluas $622,31 \mathrm{Km}^{2}$ dengan persentase $50,02 \%$, jenis litologi sebagian besar sedimen klastik berbutir halus seluas $457,19 \mathrm{Km}^{2}$ dengan persentase 36,75\%, tekstur tanah agak halus seluas $1002,30 \mathrm{Km}^{2}$ dengan persentase $80,56 \%$, potensi air tanah kurang berpotensi seluas $773,28 \mathrm{Km}^{2}$ dengan persentase $62,15 \%$, kerawanan longsor berpotensi ringan seluas $883,70 \mathrm{Km}^{2}$ dengan persentase $71,03 \%$.

Dalam penentuan indeks potensi lahan, faktor penghambat di kabupaten Nias Utara yaitu litologi yang didominasi oleh sedimen klastik berbutir halus. Litologi mempengaruhi kondisi suatu lahan karena litologi merupakan awal dari pembentukan. Jenis tanah di suatu wilayah yang berpengaruh terhadap kesuburan tanah (Muttaqin, Taryono, dan Sigit, 2016). Karakteristik litologi tersebut menyebabkan jenis tanah di kabupaten Nias Utara didominasi oleh tanah bertekstur agak halus. Tekstur tanah agak halus di Kabupaten Nias Utara termasuk kelas lempung liat berpasir (BPDAS Barumun, 2016).

Menurut Hardjowigeno (1987), tanah yang bertekstur pasir mempunyai luas permukaan yang kecil sehingga sulit menyerap (menahan) air dan unsur hara, sedangkan tanah bertekstur liat mempunyai luas permukaan yang besar sehingga kemampuan menahan air dan menyediakan unsur hara tinggi. Berdasarkan hal tersebut, maka tanah bertekstur agak halus memiliki kemampuan yang sedikit dalam menyerap (menahan) air / unsur hara. Hal tersebut sesuai dengan potensi air tanah di kabupaten Nias Utara yang sebagian besar berpotensi rendah atau kurang berpotensi. Keadaan air tanah yang rendah menurunkan tingkat kesuburan tanah. Menurut Yentri dan Taryono (2016), air tanah berpengaruh terhadap potensi lahan, produksi air tanah yang baik akan berpengaruh terhadap kualitas lahan pertanian terutama dalam hal kesuburan tanah. Air tanah penting untuk pertumbuhan tanaman dan reaksi-reaksi kimia dalam pelapukan mineral (Hardjowigeno, 1987).

Ditinjau dari faktor kemiringan lereng, wilayah kabupaten Nias Utara memiliki karakteristik kemiringan lereng yang sebagian besar berombak-bergelombang (5-15\%) yang menunjang dalam penggunaan lahan pertanian padi sawah. Menurut Sartohadi, Suratman, dan Dewi (2013), lahan rawan erosi terletak pada lahan dengan sudut lereng $>15 \%$. Menurut Beasley (1972) dalam Hardjowigeno (1987), erosi menyebabkan penurunan produktivitas tanah, kehilangan unsur hara, kualitas tanaman menurun, laju infiltrasi dan kemampuan tanah menahan air berkurang, dan banyak dampak lainnya yang menyebabkan kerusakan tanah. Sedangkan berdasarkan faktor kerawanan bencana longsor, wilayah kabupaten Nias Utara memiliki kerawanan longsor dominan ringan sehingga menunjang dalam penggunaan lahan pertanian padi sawah. Longsor dapat menyebabkan lahan pertanian hilang karena tertimbun oleh material longsor atau ambles menjadi cekungan yang dalam sehingga tak dapat ditanami lagi (Rachman, 2017).

\section{Potensi Lahan Pertanian Padi Sawah di Kabupaten Nias Utara}

Kelas potensi lahan pertanian padi sawah di kabupaten Nias Utara didominasi oleh kelas rendah dan kelas sedang. Klasifikasi Indeks potensi lahan di Kabupaten Nias Utara dapat dilihat pada gambar 1 dan tabel 6 . 


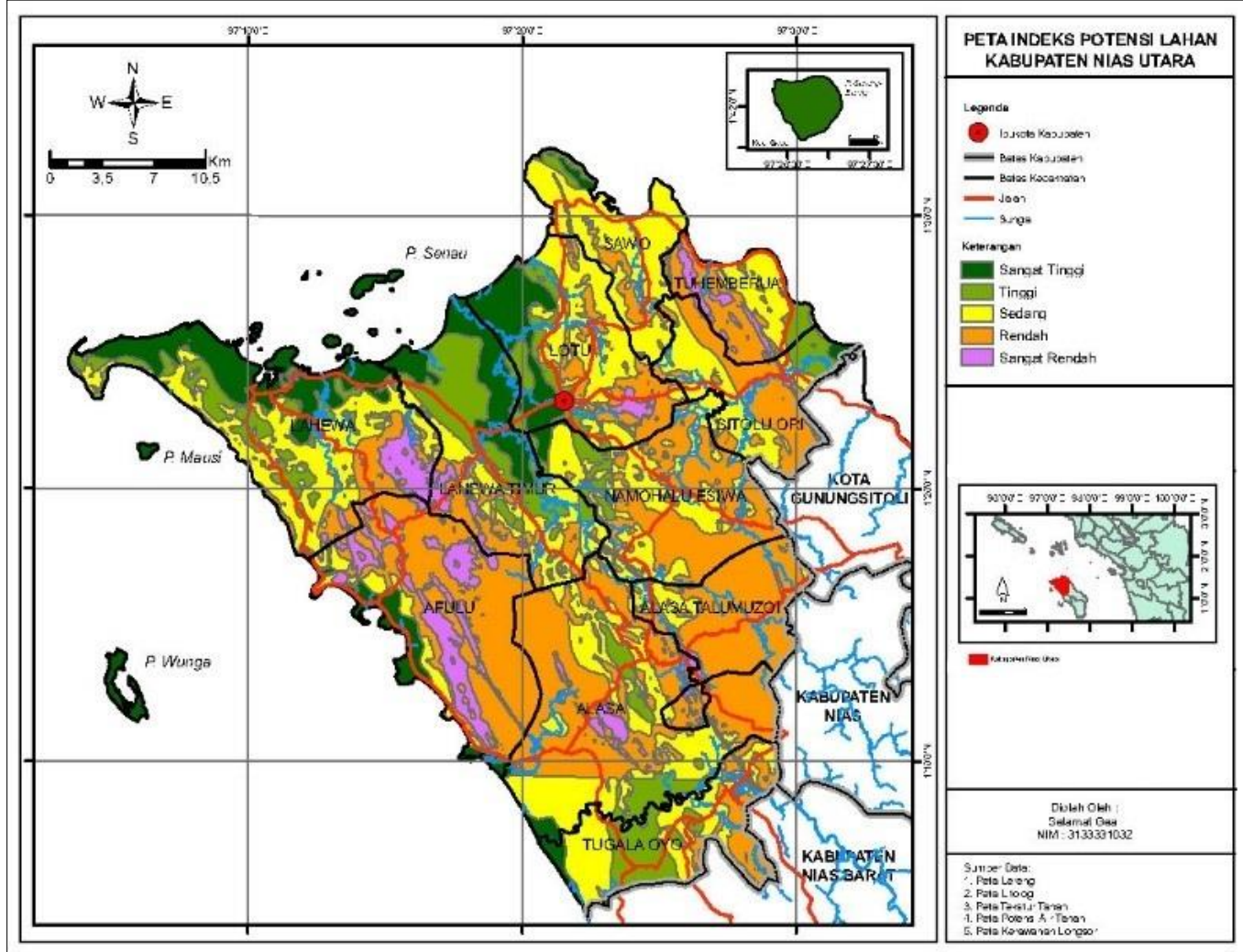

Gambar 1. Peta Indeks Potensi Lahan Kabupaten Nias Utara

TABEL 6. KLASIFIKASI POTENSI LAHAN PERTANIAN PADI SAWAH KABUPATEN NIAS UTARA

\begin{tabular}{lrr}
\hline \multicolumn{1}{c}{ Kelas } & \multicolumn{1}{c}{ Luas (Ha) } & Persentase (\%) \\
\hline Sangat Rendah & $7.182,08$ & $5,77 \%$ \\
Rendah & $46.554,24$ & $37,42 \%$ \\
Sedang & $40.770,89$ & $32,77 \%$ \\
Tinggi & $15.529,58$ & $12,48 \%$ \\
Sangat Tinggi & $14.381,44$ & $11,56 \%$ \\
\hline Jumlah & $\mathbf{1 2 4 . 4 1 8 , 2}$ & $100,00 \%$ \\
\hline \multicolumn{2}{l}{ Sumber : Pengolahan data, 2018 }
\end{tabular}

Keseluruhan potensi lahan tinggi dan sangat tinggi seluas 29.911,02 $\mathrm{Ha}$ atau 24,04\% dari total luas lahan di Kabupaten Nias Utara. Potensi lahan sangat menentukan kemampuan lahan suatu daerah dan menentukan penggunaan lahan beserta pengelolaan yang tepat sehingga dapat dicapai produktivitas yang optimal (Toyibulah, 2012).

Menurut Ditjen Tanaman Pangan (2013) dalam Indah et al., (2015), produktivitas potensial padi sawah sebesar 6,49 ton/ha.

Jika diasumsikan lahan berpotensi tinggi dan sangat tinggi seluas 29.911,02 Ha dimanfaatkan untuk pengunaan lahan pertanian padi sawah beserta pengelolaan yang tepat, maka kabupaten Nias Utara berpotensi dapat memproduksi padi sawah sebesar 194.122,52 ton atau jika dikonversi ke beras sebesar 62,74
\% (BPS dan Ditjen Kementan dalam Suhari, 2017), maka kabupaten Nias Utara berpotensi dapat memproduksi beras sebesar 121.792,46 ton/tahun atau $121.792 .460 \mathrm{~kg} /$ tahun.

Rata-rata konsumsi beras per kapita/tahun sebesar 114,6 kg/kapita/tahun (Kementerian Pertanian, 2018). Jika dikaitkan dengan jumlah penduduk kabupaten Nias Utara tahun 2016 sebesar 135.013 orang, maka kebutuhan beras di kabupaten Nias Utara sebesar 15.472.489,8 $\mathrm{kg} /$ tahun.

Berdasarkan hal tersebut, maka kabupaten Nias Utara berpotensi mampu memenuhi kebutuhan beras diwilayahnya, bahkan berpotensi surplus beras sebesar 106.319,97 ton/tahun, sehingga kabupaten Nias Utara berpotensi mampu melakukan swasembada beras.

Kelas IPL penggunaan lahan pertanian padi sawah di Kabupaten Nias Utara

Berdasarkan hasil tumpang susun (overlay) peta indeks potensi lahan padi sawah dengan peta penggunaan lahan padi sawah, kelas IPL penggunaan lahan pertanian padi sawah terdiri dari lima kelas yaitu sangat tinggi, tinggi, sedang, rendah, sangat rendah. Kelas IPL penggunaan lahan pertanian padi sawah dapat dilihat pada Tabel 7 dan Gambar 2. 
TABEL 7. KELAS IPL PENGGUNAAN LAHAN PERTANIAN PADI SAWAH DI KABUPATEN NIAS UTARA

\begin{tabular}{crr}
\hline Kelas & Luas (Ha) & Persentase (\%) \\
\hline Sangat Rendah & 61,74 & $1,54 \%$ \\
Rendah & $1.476,40$ & $36,77 \%$ \\
Sedang & $1.633,98$ & $40,69 \%$ \\
Tinggi & 466,92 & $11,63 \%$ \\
Sangat Tinggi & 376,42 & $9,37 \%$ \\
\hline Jumlah & \multicolumn{2}{c}{$\mathbf{1 0 0 , 0 0 \%}$} \\
\hline
\end{tabular}

Sumber: Pengolahan Data, 2018

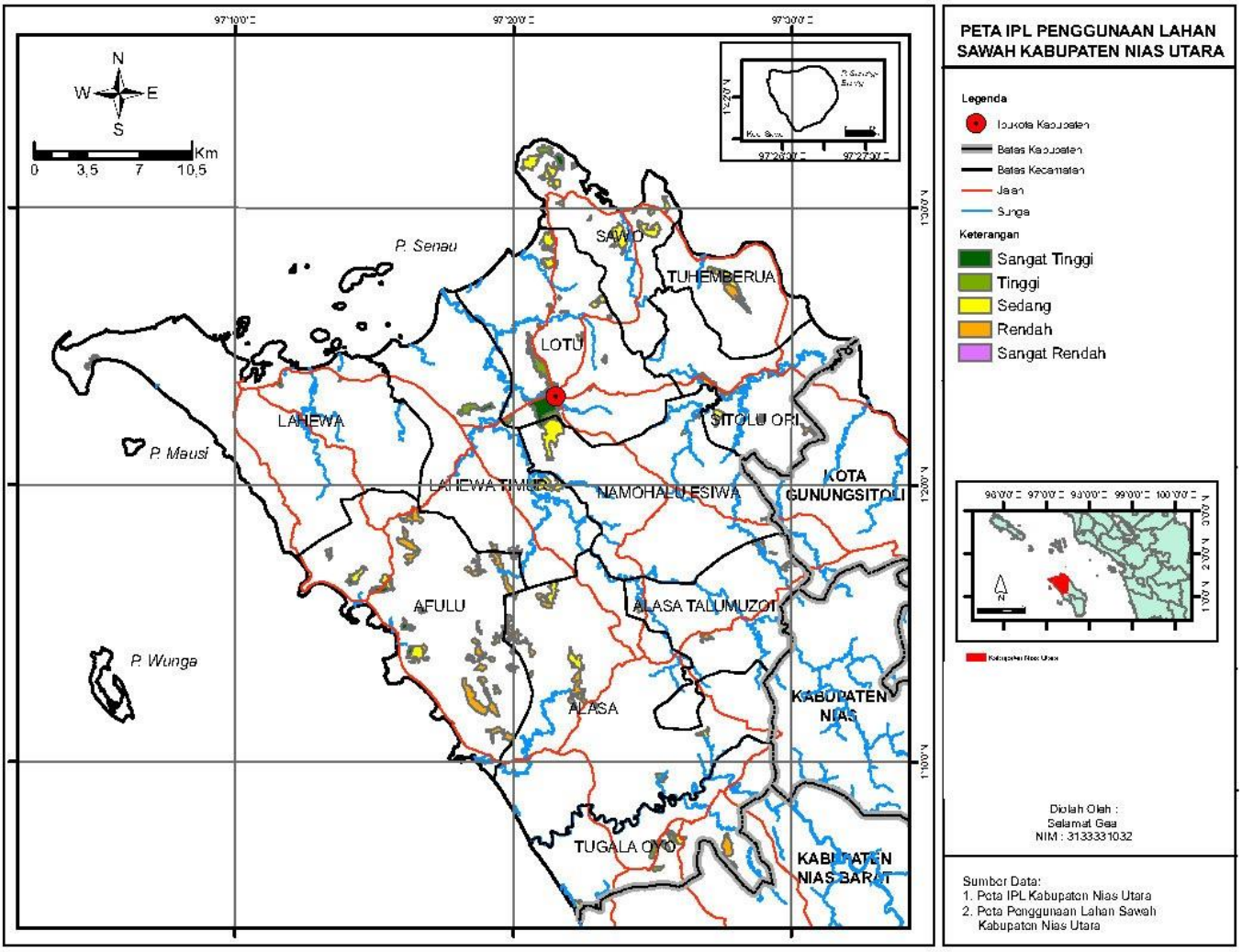

Gambar 2. Peta IPL Penggunaan Lahan Pertanian Padi Sawah di Kabupaten Nias Utara

Penggunaan lahan pertanian padi sawah di kabupaten Nias Utara sebagian besar berada di kelas IPL sedang dan rendah, hal tersebut berakibat terhadap produktivitas padi sawah di wilayah tersebut. Berdasarkan data BPS, rata-rata produktivitas padi sawah di kabupaten Nias Utara selama 5 tahun terakhir (2012-2016) sebesar 3,19 ton/tahun. Sedangkan produktivitas potensial padi sawah sebesar 6,49 ton/ha (BPS dan Ditjen Kementan dalam Suhari. 2017).

Hal tersebut menunjukkan bahwa lahan sawah yang kurang berpotensi mempengaruhi penurunan produktivitas padi sawah. Menurut Yentri dan Taryono (2016), padi yang ditanam pada lahan sawah yang berpotensi tinggi dapat menghasilkan padi yang berkualitas, produktivitas tinggi serta memiliki nilai ekonomis yang tinggi.

\section{KESIMPULAN DAN SARAN}

Berdasarkan hasil penelitian dan pembahasan, maka hasil penelitian dapat disimpulkan sebagai berikut:

1. Karakteristik fisik wilayah Kabupaten Nias Utara terdiri dari: sebagian besar memiliki lereng berombakbergelombang, litologi sediment klastik berbutir halus, tekstur tanah agak halus, potensi air tanah kurang berpotensi, kerawanan longsor berpotensi ringan.

2. Potensi lahan pertanian padi sawah di Kabupaten Nias Utara dominan pada kelas rendah $(37,42 \%)$ dan sedang (32,77\%). 
3. Kelas IPL penggunaan lahan pertanian padi sawah yang paling dominan di Kabupaten Nias Utara adalah kelas sedang $(40,69 \%)$ dan $(36,77 \%)$, dan rendah.

Adapun yang dapat disarankan dari penelitian ini adalah:

1. Perlu perlindungan untuk lahan pertanian berkelanjutan sebagai upaya menghambat alih fungsi lahan pertanian ke non-pertanian terutama pada daerah yang berpotensi tinggi.

2. Lahan pertanian padi sawah yang berpotensi tinggi dan sangat tinggi sebaiknya diolah lebih maksimal agar produktivitasnya tinggi

3. Untuk memperoleh produktivitas yang tinggi, selain penentuan lokasi yang berpotensi juga harus mementingkan aspek eksternal produktivitas seperti kualitas bibit, pengawasan hama, cuaca, serta memiliki kemampuan budidaya.

\section{DAFTAR PUSTAKA}

Arsyad, S. (1989). Konservasi tanah dan air. IPB press. Bogor.

BPDAS Barumun. (2016). Peta Tanah DAS Barumun.

BPS Kabupaten Nias Utara. (2017). Nias Utara Dalam Angka 2017.

Halengkara, L. (2007). Aplikasi Penginderaan Jauh untuk Kajian Keserasian Potensi Lahan dan Kependudukan di Kabupaten Sleman. Skripsi.

Hamranani, G. (2014). Analisis Potensi Lahan Pertanian Sawah Berdasarkan Indeks Potensi Lahan (Ipl) Di Kabupaten Wonosobo HAL AMAN. Universitas Muhammadiyah Surakarta.

Hardjowigeno, S. (1987). Ilmu tanah.

Hidayati, I. N., dan Toyibullah, Y. (2011). Kajian Indeks Potensi Lahan Terhadap Pemanfaatan Rencana Tata Ruang Wilayah Menggunakan Sistem Informasi Geografis Di Kabupaten Sragen. MAJALAH ILMIAH GLOBE, 13(2).

Indah, L. S. M., Zakaria, W. A., dan Prasmatiwi, F. E. (2015). Analisis Efisiensi Produksi dan Pendapatan USAhatani Padi Sawah pada Lahan Irigasi Teknis dan Lahan Tadah Hujan di Kabupaten Lampung Selatan. Jurnal IImu-IImu Agribisnis, 3(3).

Kementerian Pertanian (2015). Rencana
Strategis Kementerian Pertanian Tahun 2015-2019, Jakarta (ID): Kementerian Pertanian Republik Indonesia.

Kementerian Pertanian. (2018). Optimis Produksi Beras 2018 , Kementan Pastikan Harga Beras Stabil. Retrieved April 21, 2018, from http://www1.pertanian.go.id/ap_posts/de til/1555/2018/04/10/14/47/51/Optimis Produksi Beras 2018 - Kementan Pastikan Harga Beras Stabil

Muttaqin, A. A., Taryono, I., dan Sigit, A. A. (2016). Analisis Potensi Lahan (Pertanian Pangan) Berdasarkan Nilai Indeks Potensi Lahan Kabupaten Bantul. Universitas Muhammadiyah Surakarta.

Norsalis, E. (2011). Padi Sawah Dan Padi Gogo Tinjauan Secara Morfologi, Budidaya dan Fisiologi. Author: Eko Norsalis. Publish, 3, 33.

Rachman, A. (2017). Tanah Longsor Ancam Pasokan Pangan. Retrieved from http://m.mediaindonesia.com/read/detail/ 100236-tanah-longsor-ancam-pasokanpangan

Sartohadi, J., Suratman, J., dan Dewi, N. I. S. (2013). Pengantar geografi tanah. Yogyakarta: Pustaka Pelajar.

Suhari, I. (2017). Konversi Gabah Menjadi Beras 62,74\%, Tahukah Anda Darimana Angka Itu Berasal? Retrieved from www.kompasina.com/iswadi.suhari/ konversi-gabah-menjadi-beras-62-74persen-tahukah-anda-darimana-angka-ituberasal-550a08e7a33119e6c2e39bc,

Suryantoro, A. (2013). Integrasi Aplikasi Sistem Informasi Geografis. Yogyakarta: Ombak.

Toyibulah, Y. (2012). Evaluasi Rencana Tata Ruang Wilayah Berdasarkan Indeks Potensi Lahan Melalui Sistem Informasi Geografis Di Kabupaten Sragen. Universitas Muhammadiyah Surakarta.

Yentri, V. F., dan Taryono, I. H. (2016). Analisis Potensi Lahan Padi Sawah di Kabupaten Majalengka Provinsi Jawa Barat. Universitas Muhammadiyah Surakarta. 
available at http://jurnal.unimed.ac.id/2012/index.php/tgeo e-ISSN: 2622-9528 p-ISSN: 2301-606X 